\title{
Ketoprofen affects the mammary immune response in dairy cows in vivo and in vitro
}

\author{
Denisa Dan, Rupert M. Bruckmaier, and Olga Wellnitz ${ }^{1}$ \\ Veterinary Physiology, Vetsuisse Faculty, University of Bern, 3001 Bern, Switzerland
}

\begin{abstract}
Nonsteroidal anti-inflammatory drugs are commonly administered parenterally in addition to antimicrobial mastitis therapy to increase the well-being of the diseased animal. As mastitis is usually a localized infection of mammary tissue, we tested the hypothesis that a local administration of nonsteroidal anti-inflammatory drugs through the teat canal could have anti-inflammatory effects on the affected area. We investigated the effects of intramammarily administered ketoprofen (KET) during an LPS-induced immune response on somatic cell count (SCC) and blood-milk barrier integrity. In addition, we investigated the effects of KET on the mRNA abundance of immune factors and their prostaglandin E2 secretion in primary bovine mammary epithelial cells in vitro. Six cows received $0.2 \mu \mathrm{g}$ of LPS (serotype O26:B6) together with $50 \mathrm{mg}$ of KET into one quarter and LPS only in the opposing quarter. The increase of SCC and of serum albumin (SA) and IgG concentrations and the increase of lactate dehydrogenase (LDH) activity in milk induced by LPS were lower in quarters that received KET in addition. In 3 cows, intramammary KET $(50 \mathrm{mg}$ ) without additional LPS did not affect SCC, SA, IgG, and LDH in milk. Effects of KET on the immune response of mammary epithelial cells in vitro were investigated in cells from 3 cows challenged with or without LPS $(0.2 \mu \mathrm{g} / \mathrm{mL})$ and with or without additional KET in 2 concentrations (1.25 or $2.5 \mathrm{mg} /$ $\mathrm{mL})$. Ketoprofen reduced the LPS-induced increase of mRNA abundance of tumor necrosis factor $\alpha$, IL-8, serum amyloid A, and cyclooxygenase- 2 . The mRNA abundance of cyclooxygenase- 1 and prostaglandin E synthase was reduced in cells without LPS challenge by addition of KET at $2.5 \mathrm{mg} / \mathrm{mL}$. Furthermore, the LPS-induced secretion of prostaglandin E2 of mammary epithelial cells into the supernatant could not be
\end{abstract}

Received May 9, 2018.

Accepted August 2, 2018.

${ }^{1}$ Corresponding author: olga.wellnitz@vetsuisse.unibe.ch detected if KET was added. The results demonstrate that intramammary KET diminishes the increase of SCC and reduces the impairment of the blood-milk barrier (based on SA and LDH in milk), leading to a reduced IgG concentration in milk during LPS-induced mastitis. In mammary epithelial cells, KET limits the expression of several immune factors that are increased during an immune response. In summary, intramammary administration of KET reduces the inflammatory response in the mammary gland. However, it remains unclear whether the inhibited transfer of immune cells and IgG from blood into milk after KET administration would reduce the success of the immune defense in infectious mastitis.

Key words: mastitis, blood-milk barrier, nonsteroidal anti-inflammatory drug, ketoprofen

\section{INTRODUCTION}

Nonsteroidal anti-inflammatory drugs (NSAID) are increasingly used in therapy strategies for mastitis in dairy cows (Kayitsinga et al., 2017). These drugs reduce pain, fever, and signs of inflammation mainly by binding to and inhibiting the effects of cyclooxygenases $(\mathbf{C O X})$, key enzymes in prostaglandin (PG) synthesis (Llorens et al., 2002). In support of antimicrobial mastitis therapy, NSAID are administered parenterally to increase the well-being of the cow. Positive effects on the cure rate of mastitis by NSAID may also be related to the prevention of a reduced feed intake, which can have negative effects on udder health (O'Rourke, 2009). It was previously shown that flunixin meglumine can prevent reduced DMI during Escherichia coli mastitis (Yeiser et al., 2012).

Ketoprofen (KET) is an NSAID that is used for the treatment of mastitis in cows because of its short half-life, fast onset of action, and low toxicity (Kantor, 1986). It has been reported that KET has positive effects on the cure rate of mastitis and on well-being during mastitis (rectal temperature, ruminal contraction, or respiratory rate) after systemic administration (Shpigel et al., 1994; Banting et al., 2008). In calves, effects of KET on the systemic immune response after 
intravenous LPS challenge were shown by a reduction of clinical effects such as fever (Plessers et al., 2016). In mastitis treatment, the goal is the abolishment of an excessive immune response to enhance the general condition of the cow, but an effective immune response for elimination of the pathogens should be maintained.

The mammary gland is an organ suitable for a facile local administration of drugs through the teat canal. To the best of our knowledge, effects of an intramammary application of NSAID, and specifically of KET, on the mammary immune system have not yet been investigated.

The use of LPS to induce a mammary immune response is an established model, which allows the study of the immune response of the mammary gland in vivo (Bruckmaier et al., 1993; Wellnitz et al., 2011) and of mammary epithelial cells (MEC) in vitro (Wellnitz and Kerr, 2004). The mammary immune response is characterized by the expression of proinflammatory cytokines such as tumor necrosis factor $\alpha(\mathbf{T N F} \boldsymbol{\alpha})$ and IL-1 $\beta$ (Schmitz et al., 2004) and acute phase proteins such as serum amyloid A (SAA; Eckersall et al., 2001). Furthermore, $\mathrm{PG}$ plays a role in the mediation of acute inflammation symptoms such as redness, swelling, pain, and fever (Ricciotti and FitzGerald, 2011).

During mastitis, the SCC in milk increases due to a transfer of mainly phagocytic neutrophil granulocytes from blood into milk to eliminate the invaded pathogens (Sarikaya et al., 2005). As shown in a study in more than 10,000 animals, the addition of an NSAID to an antibiotic treatment of mastitis led to a decrease of quarter SCC and a reduced culling rate (McDougall et al., 2009). In the healthy lactating mammary gland, the blood-milk barrier prevents the uncontrolled transfer of blood components into milk and milk components into blood. However, during LPS-induced mastitis, the integrity of the blood-milk barrier is compromised (Lehmann et al., 2013). An opening of the blood-milk barrier is characterized by an increase of blood components such as lactate dehydrogenase (LDH) and serum albumin (SA) in milk (reviewed by Bruckmaier and Wellnitz, 2017). Furthermore, immunoglobulins are increasingly transferred from blood into milk through the impaired blood-milk barrier during mastitis independent of their pathogen specificity (Lehmann et al., 2013).

The aim of this study was to test the hypothesis that the direct contact of KET with mammary cells in vivo and in vitro affects the immune response. Ketoprofen was intramammarily administered, and effects on the SCC and the blood-milk barrier in vivo with and without additional LPS challenge were investigated. Furthermore, effects of interactions of KET with the immune response of primary MEC alone and in combination with an LPS challenge were studied in vitro.

\section{MATERIALS AND METHODS}

\section{Experiment 1: Effects of Intramammary KET In Vivo}

Experimental Animals. Nine dairy cows (Holstein Friesian and Red Holstein) in mid lactation $(179 \pm 25$ DIM) with an SCC below $150 \times 10^{3}$ cells $/ \mathrm{mL}$ in all quarters on 3 consecutive days before the experiment and no signs of clinical mastitis were used. Cows were housed in straw- and sawdust-bedded tiestalls and fed roughage ad libitum and concentrates according to their individual production levels. Animal experiments were approved by the Cantonal Committee of Animal Experiments (Fribourg, Switzerland).

Intramammary Challenge and Sampling. Intramammary challenges were performed immediately after morning milking. All injections had an end volume of $10 \mathrm{~mL}$. Ketoprofen (Sigma-Aldrich, Buchs, Switzerland) was diluted in $99 \%$ ethanol to a concentration of $50 \mathrm{mg} / \mathrm{mL}$ and then further diluted with saline solution $(0.9 \%)$. The control treatment contained $10 \%$ ethanol in saline solution. The endotoxin challenge contained $0.2 \mu \mathrm{g}$ of LPS (serotype O26:B6; Sigma-Aldrich) solved in saline solution $(0.9 \%)$. Three cows received $50 \mathrm{mg}$ of KET in one quarter and a control injection in the opposing quarter. Six cows received LPS only in one quarter and LPS and KET in the opposing quarter. Only the front quarters of cows were used for this experiment. Milk samples $(\sim 10 \mathrm{~mL})$ were taken by hand milking every 30 min until 6 and $9 \mathrm{~h}$ after challenge. Rectal temperature was measured before and every $3 \mathrm{~h}$ until $9 \mathrm{~h}$ after challenge.

Laboratory Analyses. The SCC was measured in milk samples using a DeLaval cell counter (DCC, DeLaval, Tumba, Sweden). For the measurement of LDH activity, milk serum was obtained by centrifugation at $1,900 \times g$ for $15 \mathrm{~min}$ at $4^{\circ} \mathrm{C}$ and then at $20,800 \times g$ for $30 \mathrm{~min}$ at $4^{\circ} \mathrm{C}$. The $\mathrm{LDH}$ activity was determined using the commercial kit AXON00025 (Axon-Lab AG, Baden, Switzerland) using an automated analyzer (Cobas Mira, Roche Diagnostics, Basel, Switzerland) according to the manufacturer's protocol. The concentrations of SA and IgG in milk were analyzed by ELISA kits no. E10-113 and no. E10-118 (Bethyl Laboratories, Montgomery, TX), respectively, according to the manufacturer's instructions using a Synergy Mx plate reader (BioTek Instruments, Winooski, VT). The inter- and intra-assay coefficients of variation were 3.4 and $8.4 \%$, respectively, for SA and 4.8 and $8.9 \%$, respectively, for IgG. 


\section{Experiment 2: Effects of KET on MEC In Vitro}

Isolation and Challenge of Bovine MEC. Three lactating Holstein cows were randomly selected as cell donors. The cows were $185 \pm 98$ DIM. The udders had no macroscopic signs of inflammation, and tissue samples tested negative for bacteria, including mycoplasma, at the Institute of Veterinary Bacteriology, University of Bern, Switzerland. Mammary tissue was collected within 30 min after slaughter, and the isolation and cryopreservation of MEC was performed according to Wellnitz and Kerr (2004).

For the experiment, MEC from each of the 3 cows were cultured separately in Dulbecco's modified Eagle medium/F12 containing 10\% fetal bovine serum, 1\% penicillin-streptomycin, and $1 \%$ insulin-transferrinsodium selenite media supplement. After reaching approximately $80 \%$ of confluency, cells were trypsinized and seeded at a concentration of $1.5 \times 10^{5}$ cells/well into 6 well plates and grown up to approximately $70 \%$ confluency. Immediately before starting the challenge, the growth medium was exchanged to Dulbecco's modified Eagle medium/F12 containing 3\% fetal bovine serum, $1 \%$ penicillin-streptomycin, and $1 \%$ insulintransferrin-sodium selenite media supplement $(0.5 \mathrm{mg} /$ $\mathrm{mL}$ of insulin, $0.5 \mathrm{mg} / \mathrm{mL}$ of apo-transferrin, $0.5 \mu \mathrm{g} /$ $\mathrm{mL}$ of sodium selenite; Sigma-Aldrich). For the challenge, KET was dissolved in $99 \%$ ethanol to a concentration of 0.05 or $0.1 \mathrm{mg} / \mu \mathrm{L}$ and mixed thoroughly. Cell challenge was performed by adding $25 \mu \mathrm{L}$ of KET solution to final concentrations of 1.25 and $2.5 \mathrm{mg} / \mathrm{mL}$ of cell culture medium. Lipopolysaccharide $(0.2 \mu \mathrm{g} / \mathrm{mL}$; serotype O26:B6, Sigma-Aldrich) was directly dissolved in cell culture medium.

The cells from each cow $(\mathrm{n}=3)$ were challenged separately in duplicate with the following treatments: control (receiving just $25 \mu \mathrm{L}$ of ethanol), concentration of $1.25 \mathrm{mg} / \mathrm{mL}$ of cell culture medium, concentration of $2.5 \mathrm{mg} / \mathrm{mL}$ of cell culture medium, LPS, or KET in both concentrations with additional LPS challenge. Cells were harvested at 3,6 , or $24 \mathrm{~h}$ after challenge. The supernatants of cells stimulated for $24 \mathrm{~h}$ were frozen at $-80^{\circ} \mathrm{C}$ until $\mathrm{PGE}_{2}$ analysis.

mRNA Quantification by Reverse-Transcription Real-Time PCR. Total RNA from the cells was extracted using the Direct-zol RNA MiniPrep (Zymo Research Corp., Irvine, CA) according to the manufacturer's protocol. Total RNA yield and purity were determined by absorbance at 260 and $280 \mathrm{~nm}$ using a NanoDrop-2000 spectrophotometer (Thermo Fisher Scientific, Waltham, MA). Total RNA (500 ng) was reverse transcribed by 200 units of Moloney murine leukemia virus reverse transcriptase (Promega Corp.,
Madison, WI) using 100 pmol of random hexamer primers (Invitrogen, Leek, the Netherlands).

Quantitative real-time PCR analysis was performed with the Sensimix DNA kit (Quantace, Biolabo, Chatel St. Denis, Switzerland) on a Rotor-Gene 6000 (Corbett Research, Sydney, Australia). Primers for the housekeeping (GAPDH, UBQ, and 18S) and target genes were synthesized commercially (Microsynth, Balgach, Switzerland). Sequences are shown in Table 1. Amplification efficiencies of all primers were tested in pooled cDNA samples and were above 1.8 for all primers. Threshold values (cycle threshold; $\mathrm{Ct}$ ) were calculated by Rotor Gene software version 1.7.75 (Corbett Research). Target gene $\mathrm{Ct}$ values $(\Delta \mathrm{Ct})$ were normalized to housekeeping genes according to following equation: $\Delta \mathrm{Ct}=\mathrm{Ct}$ (arithmetic mean of housekeeping genes) $\mathrm{Ct}$ (target gene).

$P G E_{2}$ Measurement in Supernatant. The concentration of $\mathrm{PGE}_{2}$ after $24 \mathrm{~h}$ of challenge was measured using a commercial ELISA kit (no. ADI-900-001; Enzo Life Sciences, Lausen, Switzerland) according to the manufacturer's protocol. The samples were centrifuged at $1,900 \times g$ for $15 \mathrm{~min}$ at $4^{\circ} \mathrm{C}$ and then at 20,800 $\times g$ for 30 min at $4^{\circ} \mathrm{C}$. Absorbance was measured in a Synergy Mx plate reader (BioTek Instruments). The inter- and intra-assay coefficients of variation were 7.5 and $4.5 \%$, respectively.

\section{Statistical Analysis}

Results are presented as least squares means \pm standard error of the mean. Statistical analyses were performed by using the MIXED procedure of SAS (SAS version 9.4; SAS Institute Inc., Cary, NC) with Tukey-Kramer adjustment. The model included time, treatment, and the interaction between both (time $x$ treatment) as fixed effects and cow as the repeated subject for the in vivo experiment. Analyses of the in vitro experiment were performed for each time point separately, and the model included treatment as fixed and cow as random effects. Differences were considered significant when $P<0.05$.

\section{RESULTS}

\section{In Vivo Challenge}

The rectal temperature of cows that received KET only did not change. In cows that received intramammary LPS and KET, rectal temperature increased from $38.5 \pm 0.1^{\circ} \mathrm{C}$ before the experiment to $39.3 \pm 0.5^{\circ} \mathrm{C}(P$ $=0.026)$ and $39.3 \pm 0.4^{\circ} \mathrm{C}(P=0.039)$ at 6 and $9 \mathrm{~h}$ 


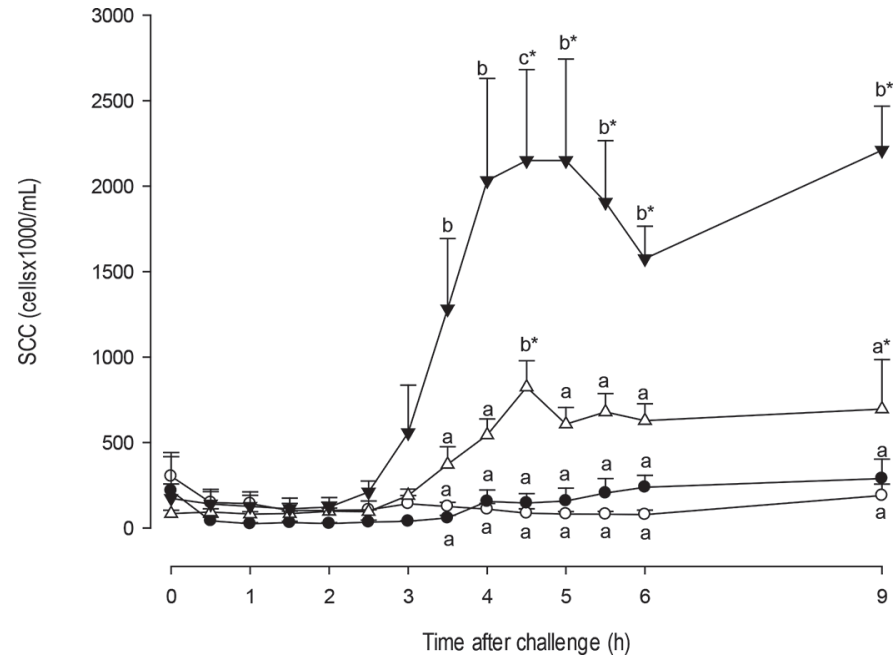

Figure 1. Somatic cell count (cells $\times 1,000 / \mathrm{mL})$ in control quarters (treated with saline solution only), quarters treated with ketoprofen (KET) only, quarters treated with LPS only, and quarters treated with LPS and KET. Data are presented as least squares means \pm SEM. $\bullet=$ mean SCC in control quarters; $\bigcirc=$ mean SCC in quarters treated with KET only; $\boldsymbol{\nabla}=$ mean SCC in quarters treated with LPS; $\Delta=$ mean SCC in quarters treated with KET and LPS. Means without common letters $(\mathrm{a}-\mathrm{c})$ indicate significant differences $(P<0.05)$ between treatments within a time point. Asterisk $(*)$ indicates a significant increase compared with time point 0 . after challenge, respectively, and returned to baseline levels $\left(38.9 \pm 0.39^{\circ} \mathrm{C}\right)$ the next day.

The SCC (Figure 1) in quarters treated only with KET showed no significant differences compared with the control quarters that received saline solution only throughout the entire experiment. In quarters that received LPS only, the SCC increased starting $4 \mathrm{~h}$ after challenge $(P<0.0001)$ and stayed elevated until the end of the experiment. The quarters that received KET in addition to LPS showed a significantly lower SCC compared with quarters that received LPS only beginning at $4 \mathrm{~h}(P=0.002)$ after challenge, and this difference remained until the end of the experiment. The activity of LDH in milk was significantly elevated in the quarters that were treated with LPS only starting at $4 \mathrm{~h}(P=0.001)$ after challenge, whereas the quarters that received KET in addition to LPS did not show an increase of LDH activity (Figure 2A). There was no change in LDH activity throughout the entire experiment in quarters that were treated with KET only or in control quarters.

The concentration of SA (Figure 2B) in milk of quarters treated with LPS only was increased $2.5 \mathrm{~h}$ after challenge $(P=0.002)$ and stayed elevated until the end of the experiment. The quarters that received KET in addition to LPS had lower SA concentrations in milk at $5 \mathrm{~h}$ postchallenge $(P=0.030)$ compared with quarters treated with LPS only, and this difference was seen until the end of the experiment. There was no

Table 1. Primer sequences for PCR, Gene Bank accession number, annealing temperature, and product length

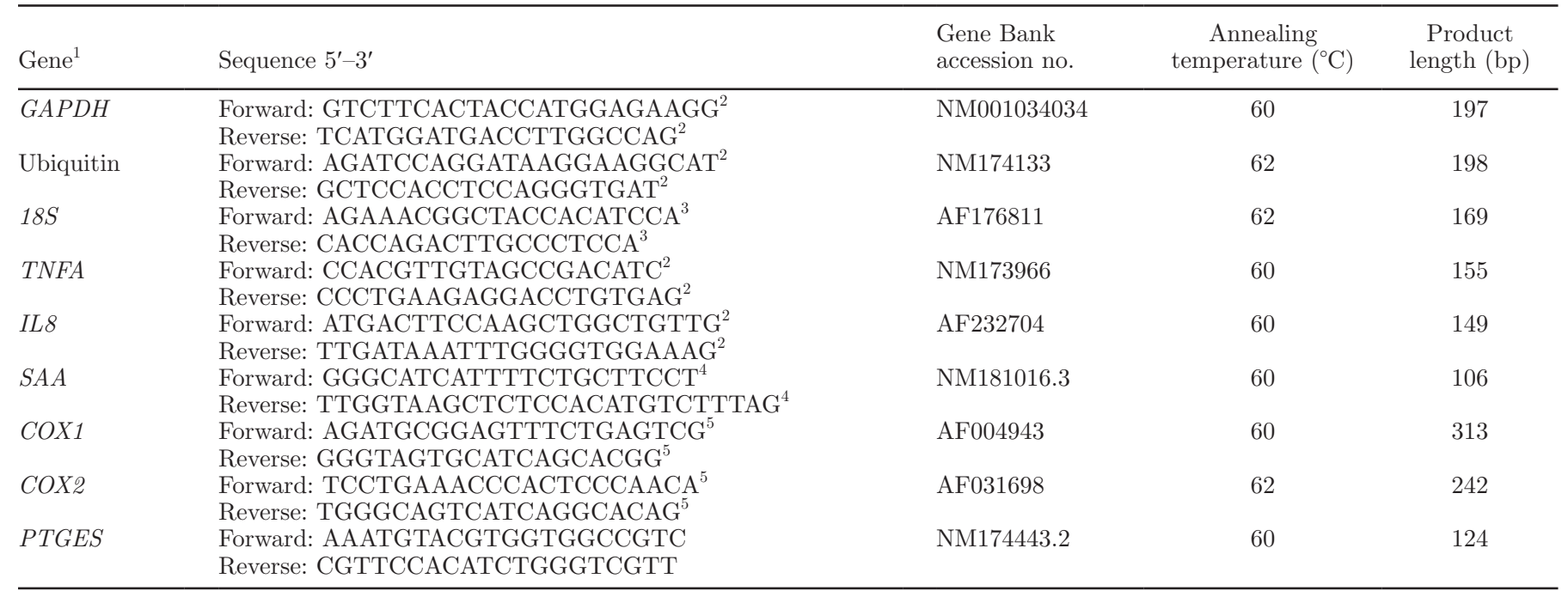

${ }^{1}$ TNFA = tumor necrosis factor $\alpha ; S A A=$ serum amyloid A; COX = cyclooxygenase PTGES = prostaglandin E synthase.

${ }^{2}$ Griesbeck-Zilch et al. (2008).

${ }^{3}$ Goossens et al. (2005).

${ }^{4}$ Mukesh et al. (2010).

${ }^{5}$ Pfaffl et al. (2003). 
difference in SA concentrations between KET-treated quarters and control quarters.

The concentration of IgG in milk (Figure 3 ) was increased in LPS-treated quarters from $3 \mathrm{~h}(P=0.016)$ and stayed elevated until $5.5 \mathrm{~h}$ after challenge. Quarters that were treated with KET in addition to LPS showed significantly lower $\operatorname{IgG}$ concentrations at 4, 5, 5.5, and $9 \mathrm{~h}$ after challenge compared with quarters treated with LPS only $(P=0.013, P=0.014, P=0.024$, and $P$ $=0.005$, respectively). Control quarters and quarters

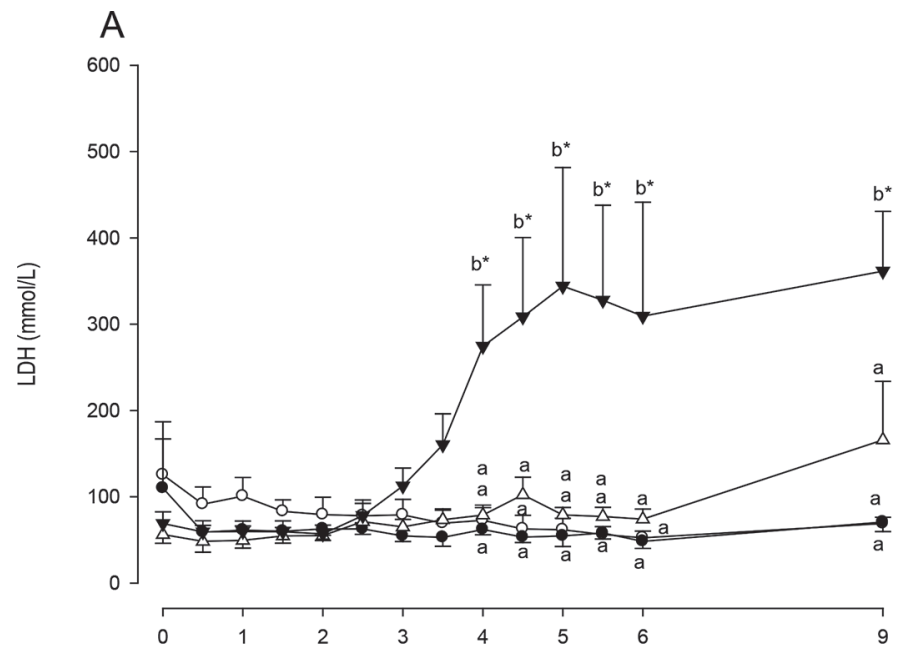

\section{B}

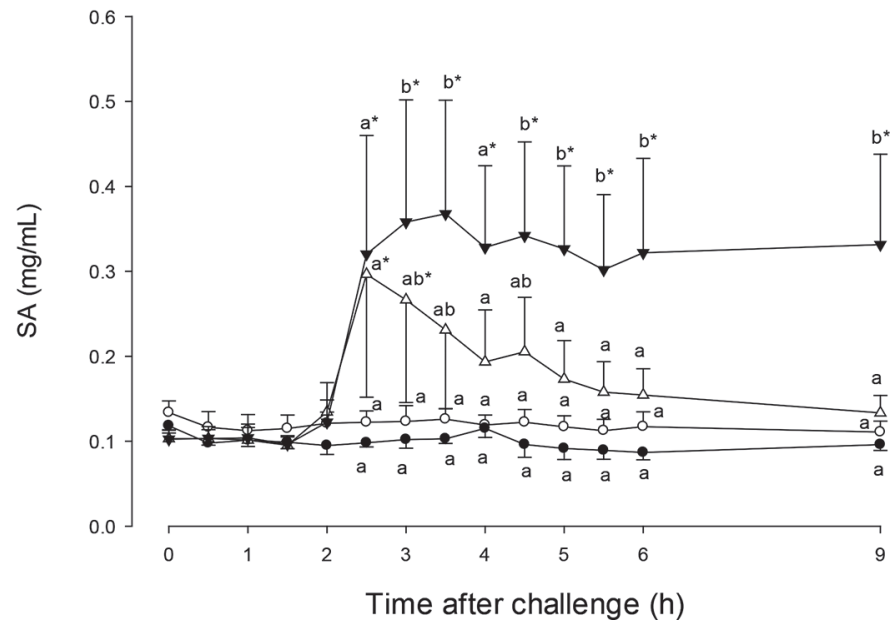

Figure 2. Lactate dehydrogenase (LDH) activity (A) and serum albumin (SA) concentrations (B) in milk of control quarters, quarters treated with ketoprofen (KET) only, quarters treated with LPS only, and quarters treated with LPS and KET. Data are presented as least squares means \pm SEM. $\bullet=$ control quarters; $\bigcirc=$ quarters treated with KET only; $\boldsymbol{\nabla}=$ quarters treated with LPS only; $\Delta=$ quarters treated with KET and LPS. Means without common letters (a,b) indicate significant differences $(P<0.05)$ between treatments within a time point. Asterisk $(*)$ indicates a significant increase compared with time point 0 .

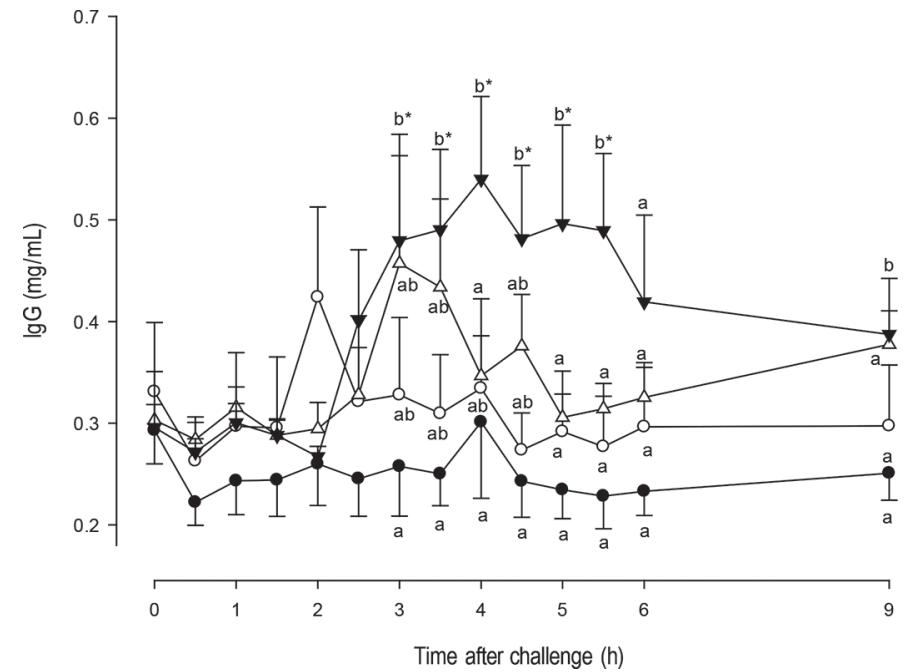

Figure 3. Immunoglobulin G concentrations in milk of control quarters (treated with saline solution only), quarters treated with ketoprofen (KET) only, quarters treated with LPS only, and quarters treated with LPS and KET. Data are presented as least squares means \pm SEM. $\bullet=$ control quarters; $\bigcirc=$ quarters treated with KET only; $\boldsymbol{\nabla}=$ quarters treated with LPS only; $\Delta=$ quarters treated with KET and LPS. Means without common letters $(\mathrm{a}, \mathrm{b})$ indicate significant differences $(P<0.05)$ between treatments within a time point. Asterisk $(*)$ indicates a significant increase compared with time point 0 .

treated with KET only showed no significant changes in IgG concentrations throughout the experiment.

\section{In Vitro Challenge of MEC}

The mRNA abundance of immune factors in challenged cells at different time points is shown in Table 2. The cells responded to the LPS challenge with an increase in mRNA abundance of TNF , IL-8, SAA, and COX-2 compared with control cells at one or more time points (see Table 2). This increase was abolished or diminished if KET was added to the cells. After $24 \mathrm{~h}$ of challenge, cells treated with KET only had a lower mRNA abundance of IL-8 than control cells $(P=$ 0.018). The mRNA abundance of COX-1 was not influenced by LPS but was downregulated with additional treatment of KET in higher concentrations after $6 \mathrm{~h}(P$ $=0.005)$. Also, the mRNA abundance of prostaglandin E synthase (PTGES) was not changed by LPS treatment, but a high concentration of KET decreased the mRNA abundance of PTGES after $6 \mathrm{~h}$ compared with all other treatments $(P \leq 0.032)$.

Concentrations of $\mathrm{PGE}_{2}$ (Figure 4) were higher in supernatants of cells challenged with LPS only compared with control cells $(P=0.045)$. In supernatants of cells treated with LPS and KET, in both concentrations the $\mathrm{PGE}_{2}$ concentrations were not different compared with supernatants of control cells. 
Table 2. Abundance of mRNA (least squares means of target cycle threshold values \pm SEM of duplicates from cells from 3 cows) of immune factors in bovine mammary epithelial cells challenged with the experimental treatments

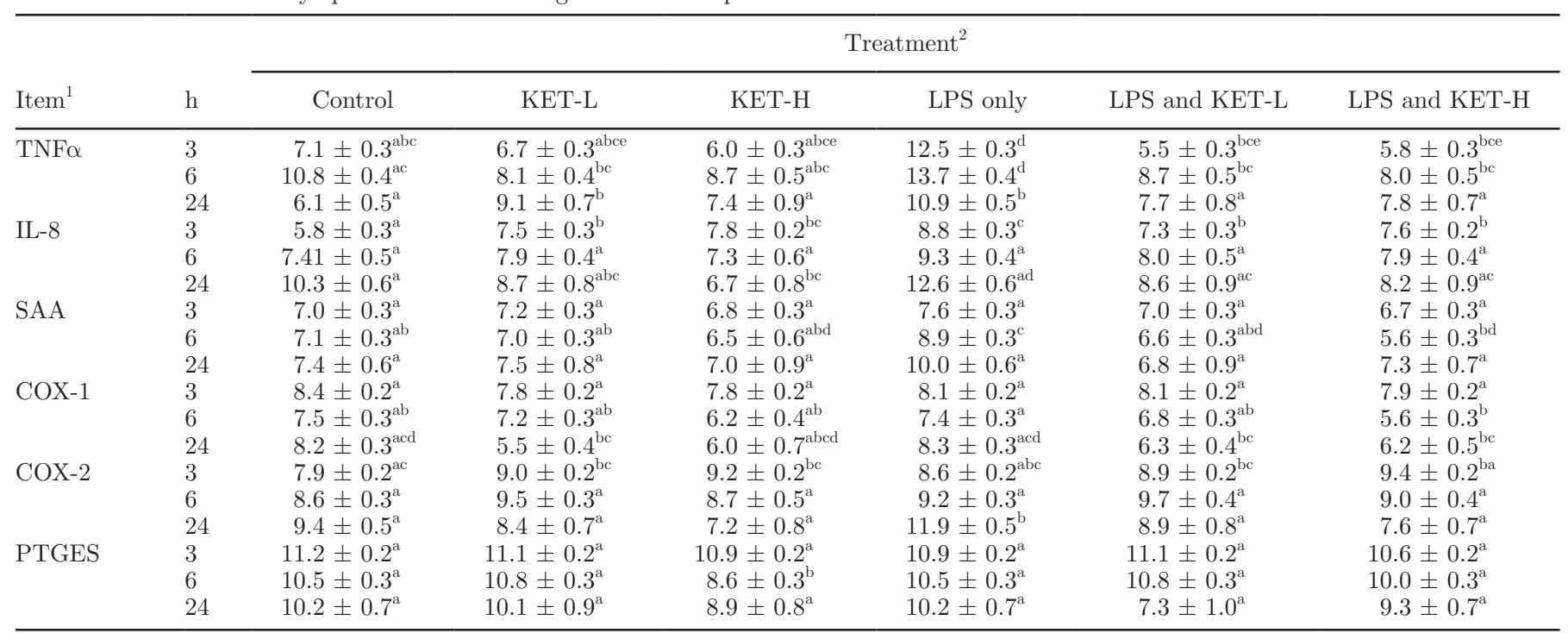

${ }^{\mathrm{a}-\mathrm{e}}$ Means within a row with different superscripts are significantly different $(P<0.05)$.

${ }^{1} \mathrm{TNF} \alpha=$ tumor necrosis factor $\alpha$; SAA = serum amyloid $\mathrm{A} ; \mathrm{COX}=$ cyclooxygenase; PTGES = prostaglandin E synthase.

${ }^{2}$ Control $=25 \mu \mathrm{L}$ of ethanol $/ \mathrm{mL}$; KET-L $=1.25 \mathrm{mg}$ of ketoprofen $/ \mathrm{mL} ;$ KET-H $=2.5 \mathrm{mg}$ of ketoprofen $/ \mathrm{mL} ; \mathrm{LPS}=0.2 \mu \mathrm{g}$ of LPS $/ \mathrm{mL}$.

\section{DISCUSSION}

The intramammary administration of $50 \mathrm{mg}$ of KET/ quarter without additional immune stimulation showed that the drug does not induce a pronounced influx of cells and does not influence the blood-milk barrier based on the measurement of the blood components $\mathrm{LDH}, \mathrm{SA}$, and IgG in milk. In previous studies, the

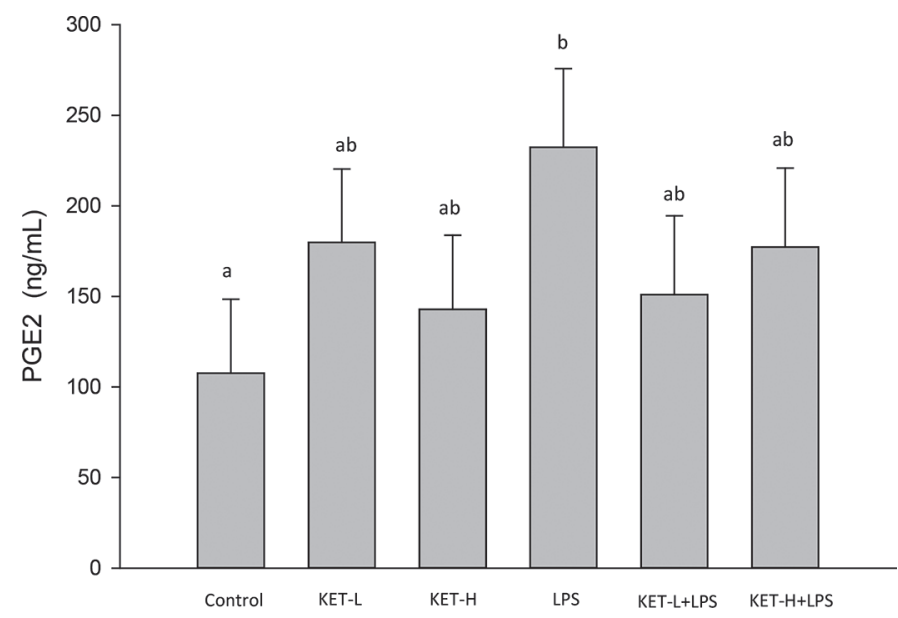

Figure 4. Prostaglandin $\mathrm{E}_{2}$ (PGE2) concentrations in supernatants of primary bovine mammary epithelial cells challenged for $24 \mathrm{~h}$ as follows: control, $1.25 \mathrm{mg} / \mathrm{mL}$ of ketoprofen (KET-L), $2.5 \mathrm{mg} / \mathrm{mL}$ of ketoprofen (KET-H), $0.2 \mu \mathrm{g} / \mathrm{mL}$ of LPS, KET-L with LPS, and KET-H with LPS. Presented are least squares means \pm SEM of duplicates from cells from 3 cows. Means without common letters $(a, b)$ are significantly different $(P<0.05)$. intramammary LPS induced an increase in rectal temperature showing systemic effects (Schmitz et al., 2004). Although orally or parenterally administered KET has antipyretic effects in cows (Banting et al., 2008), in the present study the intramammary administration of 50 $\mathrm{mg}$ of KET into one quarter did not prevent the increase in rectal temperature. Systemically administered KET is usually injected in a dosage of $3 \mathrm{mg} / \mathrm{kg}$ of BW, which is a much higher dosage; therefore, the effects of intramammarily administered KET in the used dosage seem to be restricted to the mammary gland.

The increase of SCC in LPS-challenged quarters was in agreement with other studies using comparable dosages of LPS (Wellnitz et al., 2011). The results of the present study clearly show that intramammary KET diminishes the increase of SCC in response to LPS. Previous studies in rats and mice showed that systemic and local administration of KET reduces the influx of immune cells such as leukocytes and macrophages to the pleura and peritoneum through an unknown mechanism (Vannier et al., 1989; Hamdani et al., 2015). A selective inhibition of the IL-8-induced chemotaxis of human intestinal neutrophils in vitro by KET has been reported by Bizzarri et al. (2001). Interleukin- 8 is an important chemokine in the mammary immune response, increases in milk during mastitis (Bannerman et al., 2004), and it is expressed by MEC during an immune response (Wellnitz and Kerr, 2004). Therefore, it is possible that the inhibition of IL- 8 is also involved in the reduction of SCC increase during LPS chal- 
lenge by KET. Furthermore, an increased IL- 8 mRNA abundance in MEC after LPS challenge was observed, but this increase failed to appear if KET was added. Another factor that plays a role in cell recruitment to the udder during mastitis is the acute phase protein SAA (Akerstedt et al., 2011). In the present study, the mRNA abundance of SAA in MEC after LPS challenge was reduced by additional KET challenge. Obviously, the reduction of key chemoattractant molecules by KET is involved in the reduced recruitment of somatic cells into the milk after LPS challenge. Therefore, the results clearly show that the intramammary administration of KET has an inhibitory effect on the SCC increase during mammary inflammation. However, it remains unclear whether this effect can have a negative effect on the cure rate of mastitis because these cells can perform bacterial phagocytosis (Sordillo and Streicher, 2002), and it should be further investigated.

When MEC are exposed to LPS, they lose their barrier function (Wellnitz et al., 2016). An impaired epithelial barrier in the mammary gland leads to an increased transfer of blood components into milk (Stelwagen et al., 1994; Lehmann et al., 2013). In the present study, the intramammary LPS challenge resulted in an increased LDH activity and increased SA concentration in milk. Interestingly, the quarters that additionally received KET did not show differences in $\mathrm{LDH}$ activity and SA concentration in milk compared with control quarters. This clearly shows that KET protects the blood-milk barrier integrity during an LPS-induced immune response. It is possible that the mechanism by which KET affects the blood-milk barrier is related to the effect of $\mathrm{PG}$ on tight junctions as discussed by Maule Walker and Peaker (1980) in a study in goats. The NSAID KET is known to affect PG synthesis, and effects of KET on the $\mathrm{PGE}_{2}$ synthesis in MEC in vitro were shown: cells challenged with KET and LPS had no increased $\mathrm{PGE}_{2}$ secretion like the cells challenged with LPS only. Therefore, KET clearly prevents the blood-milk barrier from leaking during LPS challenge, and a reduced local PG production might play a role in this mechanism.

The opening of the blood-milk barrier during LPS-induced mastitis allows an increased transfer of immunoglobulins from blood into milk (Rainard and Riollet, 2006; Lehmann et al., 2013), where they likely contribute to the combat against the mastitis pathogens through opsonic properties (Burton and Erskine, 2003). The addition of KET to the intramammary LPS challenge led to a decreased transfer of IgG through a diminished impairment of the blood-milk barrier Therefore, an intramammary treatment of KET could lower the efficiency of mastitis pathogen-specific antibodies that can be present in the blood (e.g., after vac- cination) and that are usually increasingly transferred from blood into milk through the impaired blood-milk barrier during mastitis.

Ketoprofen was shown to have anti-inflammatory effects in cattle by regulating cytokines that are involved in the immune response; for example, the intravenous administration of KET in calves that were challenged with LPS reduced the plasma concentration of TNFo (Plessers et al., 2016). Furthermore, Donalisio et al. (2013) showed that KET reduces the production of TNFQ in blood cells of cows after LPS challenge. In the present study, effects of KET on the mRNA abundance of selected immune factors of MEC in vitro were investigated. In preliminary experiments, the dosage of 2.5 $\mathrm{mg} / \mathrm{mL}$ of KET was shown to be the maximum amount of KET that could easily be dissolved in alcohol without adding more alcohol than $2.5 \%$ to the cell culture medium, as this affects cell growth. To investigate the dose-dependent effect, half of the maximum dosage was also applied. Mammary epithelial cells line the inner surface of the udder and therefore have direct contact with drugs administered through the teat canal. These cells were shown to play an important role in the regulation of the mammary immune response by expression of immune factors such as TNF $\alpha$, IL-8, SAA, and COX2 (Griesbeck-Zilch et al., 2008; Zbinden et al., 2014). Different times of challenge were chosen to be able to consider immune factors that are activated at different stages of the immune response. The results show that KET reduces the mRNA abundance of TNF $\alpha$, IL- 8 , SAA, and COX-2 in MEC challenged with LPS. This clearly indicates a limiting effect of KET on the immune response of MEC. Furthermore, KET reduced the mRNA abundance of COX-1 in MEC after $6 \mathrm{~h}$ of challenge. Interestingly, after a challenge with KET in both concentrations for only $3 \mathrm{~h}$, the mRNA abundance of COX-2 increased in MEC, whereas this effect was no longer visible at later time points. This may indicate a short-term counterregulation of MEC due to blocked COX-2 by KET. To evaluate further effects on PG synthesis the mRNA abundance of PTGES was measured in MEC, but only a reduction at $6 \mathrm{~h}$ and only by a high concentration of KET was detectable. However, the results of mRNA abundance of enzymes involved in the PG synthesis (COX-1, COX-2, and PTGES) indicate that KET has an effect on the PG synthesis in MEC. Effects on PG synthesis in MEC confirm the effectiveness of KET in this experiment.

\section{CONCLUSIONS}

Ketoprofen interferes with the immune response and the inflammation process in MEC by reducing the mRNA abundance of key cytokines and chemoattrac- 
tant factors and by reducing PG synthesis. Although the number of experimental animals was limited, this study shows that intramammarily administered KET limits the increase of SCC in milk that occurs during inflammation of the udder. Intramammary KET maintains the integrity of the blood-milk barrier during mammary inflammation, preventing an increase of blood constituents in milk. Thus, intramammary administration of KET for mastitis treatment could reduce inflammation of the udder and could support a fast return to a normal composition of milk. However, it reduces the IgG transfer from blood into milk that occurs specifically during mastitis induced by gram-negative bacteria. Although it remains unknown whether other antibacterial components in the milk are affected by the administration of KET, the reduction of SCC and IgG in milk during mastitis could limit the elimination of bacteria from the milk. A recommendation of an intramammary treatment with KET needs further investigation and depends on the involved pathogen.

\section{ACKNOWLEDGMENTS}

The authors thank Monica Caldeira, Claudine Morel, Chantal Philipona, and Yolande Zbinden (Veterinary Physiology, Vetsuisse Faculty, University of Bern, Switzerland) for their assistance.

\section{REFERENCES}

Akerstedt, M., L. Forsbäck, T. Larsen, and K. Svennersten-Sjaunja. 2011. Natural variation in biomarkers indicating mastitis in healthy cows. J. Dairy Res. 78:88-96. https://doi.org/10.1017/ S0022029910000786.

Bannerman, D. D., M. J. Paape, J. W. Lee, X. Zhao, J. C. Hope, and P. Rainard. 2004. Escherichia coli and Staphylococcus aureus elicit differential innate immune responses following intramammary infection. Clin. Diagn. Lab. Immunol. 11:463-472. https://doi.org/ 10.1128/CDLI.11.3.463-472.2004.

Banting, A., S. Banting, K. Heinonen, and K. Mustonen. 2008. Efficacy of oral and parenteral ketoprofen in lactating cows with endotoxin-induced acute mastitis. Vet. Rec. 163:506-509. https:// doi.org/10.1136/vr.163.17.506.

Bizzarri, C., S. Pagliei, L. Brandolini, P. Mascagni, G. Caselli, P. Transidico, S. Sozzani, and R. Bertini. 2001. Selective inhibition of interleukin-8-induced neutrophil chemotaxis by ketoprofen isomers. Biochem. Pharmacol. 61:1429-1437. https://doi.org/10 .1016/S0006-2952(01)00610-4.

Bruckmaier, R. M., M. Schällibaum, and J. W. Blum. 1993. Escherichia coli endotoxin-induced mastitis in dairy cows: Changes and importance of insulin-like growth factor I and oxytocin. Milchwissenschaft 48:374-378.

Bruckmaier, R. M., and O. Wellnitz. 2017. Pathogen-specific immune response and changes in the blood-milk barrier of the bovine mammary gland. J. Anim. Sci. 95:5720-5728. https://doi.org/10.2527/ jas2017.1845.

Burton, J. L., and R. J. Erskine. 2003. Immunity and mastitis. Some new ideas for an old disease. Vet. Clin. North Am. Food Anim. Pract. 19:1-45. https://doi.org/10.1016/0749-0720(02)00073-7.
Donalisio, C., R. Barbero, B. Cuniberti, C. Vercelli, M. Casalone, and G. Re. 2013. Effects of flunixin meglumine and ketoprofen on mediator production in ex vivo and in vitro models of inflammation in healthy dairy cows. J. Vet. Pharmacol. Ther. 36:130-139. https: //doi.org/10.1111/j.1365-2885.2012.01396.x.

Eckersall, P. D., F. J. Young, C. McComb, C. J. Hogarth, S. Safi, A. Weber, T. McDonald, A. M. Nolan, and J. L. Fitzpatrick. 2001. Acute phase proteins in serum and milk from dairy cows with clinical mastitis. Vet. Rec. 148:35-41. https://doi.org/10.1136/vr .148 .2 .35 .

Goossens, K., M. Van Poucke, A. Van Soom, J. Vandesompele, A. Van Zeveren, and L. J. Peelman. 2005. Selection of reference genes for quantitative real-time PCR in bovine preimplantation embryos. BMC Dev. Biol. 5:27. https://doi.org/10.1186/1471-213X-5-27.

Griesbeck-Zilch, B., H. H. D. Meyer, Ch. Kühn, M. Schwerin, and O. Wellnitz. 2008. Staphylococcus aureus and Escherichia coli cause deviating expression profiles of cytokines and lactoferrin messenger ribonucleic acid in mammary epithelial cells. J. Dairy Sci. 91:2215-2224. https://doi.org/10.3168/jds.2007-0752.

Hamdani, D. A., A. Javeed, M. Ashraf, J. Nazir, A. Ghafoor, and M. S. Yousaf. 2015. Effects of ketoprofen on cellular immune responses in mice. Pak. J. Zool. 47:551-557.

Kantor, T. G. 1986. Ketoprofen: A review of its pharmacologic and clinical properties. Pharmacotherapy 6:93-103. https://doi.org/10 $.1002 /$ j.1875-9114.1986.tb03459.x.

Kayitsinga, J., R. L. Schewe, G. A. Contreras, and R. J. Erskine. 2017. Antimicrobial treatment of clinical mastitis in the eastern United States: The influence of dairy farmers' mastitis management and treatment behavior and attitudes. J. Dairy Sci. 100:1388-1407. https://doi.org/10.3168/jds.2016-11708.

Lehmann, M., O. Wellnitz, and R. M. Bruckmaier. 2013. Concomitant lipopolysaccharide-induced transfer of blood-derived components including immunoglobulins into milk. J. Dairy Sci. 96:889-896. https://doi.org/10.3168/jds.2012-5410.

Llorens, O., J. J. Perez, A. Palomer, and D. Mauleon. 2002. Differential binding mode of diverse cyclooxygenase inhibitors. J. Mol. Graph. Model. 20:359-371. https://doi.org/10.1016/S1093 $-3263(01) 001358$.

Maule Walker, F. M., and M. Peaker. 1980. Local production of prostaglandins in relation to mammary function at the onset of lactation in the goat. J. Physiol. 309:65-79.

McDougall, S., M. A. Bryan, and R. M. Tiddy. 2009. Effect of treatment with the nonsteroidal anti-inflammatory meloxicam on milk production, somatic cell count, probability of re-treatment, and culling of dairy cows with mild clinical mastitis. J. Dairy Sci. 92:4421-4431. https://doi.org/10.3168/jds.2009-2284.

Mukesh, M., M. Bionaz, D. E. Graugnard, J. K. Drackley, and J. J. Loor. 2010. Adipose tissue depots of Holstein cows are immune responsive: Inflammatory gene expression in vitro. Domest. Anim. Endocrinol. 38:168-178. https://doi.org/10.1016j.domaniend.2009 .10 .001 .

O'Rourke, D. 2009. Nutrition and udder health in dairy cows: A review. Ir. Vet. J. 62(Suppl. 4):S15-S20. https://doi.org/10.1186/ 2046-0481-62-S4-S15.

Pfaffl, M. W., S. L. Wittmann, H. H. D. Meyer, and R. M. Bruckmaier. 2003. Gene expression of immunologically important factors in blood cells, milk cells, and mammary tissue of cows. J. Dairy Sci. 86:538-545. https://doi.org/10.3168/jds.S0022-0302(03)73632-7.

Plessers, E., H. Wyns, A. Watteyn, B. Pardon, S. De Baere, U. S. Stanislas, P. De Backer, and S. Croubels. 2016. Immunomodulatory properties of gamithromycin and ketoprofen in lipopolysaccharide-challenged calves with emphasis on the acute-phase response. Vet. Immunol. Immunopathol. 171:28-37. https://doi.org/ 10.1016/j.vetimm.2016.01.007.

Rainard, P., and C. Riollet. 2006. Innate immunity of the bovine mammary gland. Vet. Res. 37:369-400. https://doi.org/10.1051/vetres: 2006007.

Ricciotti, E., and G. A. FitzGerald. 2011. Prostaglandins and inflammation. Arterioscler. Thromb. Vasc. Biol. 31:986-1000. https:// doi.org/10.1161/ATVBAHA.110.207449. 
Sarikaya, H., C. Werner-Misof, M. Atzkern, and R. M. Bruckmaier. 2005. Distribution of leucocyte populations, and milk composition, in milk fractions of healthy quarters in dairy cows. J. Dairy Res. 72:486-492. https://doi.org/10.1017/S0022029905001317.

Schmitz, S., M. W. Pfaffl, H. H. D. Meyer, and R. M. Bruckmaier. 2004. Short-term changes of mRNA expression of various inflammatory factors and milk proteins in mammary tissue during LPSinduced mastitis. Domest. Anim. Endocrinol. 26:111-126. https:// doi.org/10.1016/j.domaniend.2003.09.003.

Shpigel, N. Y., R. Chen, M. Winkler, G. Ziv, and F. Longo. 1994. Anti-inflammatory ketoprofen in the treatment of field cases of bovine mastitis. Res. Vet. Sci. 56:62-68. https://doi.org/10.1016/ 0034-5288(94)90197-X.

Sordillo, L. M., and K. L. Streicher. 2002. Mammary gland immunity and mastitis susceptibility. J. Mammary Gland Biol. Neoplasia 7:135-146. https://doi.org/10.1016/j.livprodsci.2005.10.017.

Stelwagen, K., I. Politis, J. H. White, B. Zavizion, C. G. Prosser, S. R. Davis, and V. C. Farr. 1994. Effect of milking frequency and somatotropin on the activity of plasminogen activator, plasminogen, and plasmin in bovine milk. J. Dairy Sci. 77:3577-3583. https:// doi.org/10.3168/jds.S0022-0302(94)77301-X.

Vannier, E., M. Roch-Arveiller, B. Molinie, B. Terlain, and J.-P. Giroud. 1989. Effects of ketoprofen and indomethacin on leukocyte migration in two models of pleurisy induced by carrageenan or zymosan-activated serum in rats. J. Pharmacol. Exp. Ther. 248:286-291.
Wellnitz, O., E. T. Arnold, and R. M. Bruckmaier. 2011. Lipopolysaccharide and lipoteichoic acid induce different immune responses in the bovine mammary gland. J. Dairy Sci. 94:5405-5412. https:// doi.org/10.3168/jds.2010-3931.

Wellnitz, O., and D. E. Kerr. 2004. Cryopreserved bovine mammary cells to model epithelial response to infection. Vet. Immunol. Immunopathol. 101:191-202. https://doi.org/10.1016/j.vetimm.2004 .04 .019 .

Wellnitz, O., C. Zbinden, X. Huang, and R. M. Bruckmaier. 2016. Short communication: Differential loss of bovine mammary epithelial barrier integrity in response to lipopolysaccharide and lipoteichoic acid. J. Dairy Sci. 99:4851-4856. https://doi.org/10.3168/ jds.2016-10927.

Yeiser, E. E., K. E. Leslie, M. L. McGilliard, and C. S. PeterssonWolfe. 2012. The effects of experimentally induced Escherichia coli mastitis and flunixin meglumine administration on activity measures, feed intake, and milk parameters. J. Dairy Sci. 95:49394949. https://doi.org/10.3168/jds.2011-5064.

Zbinden, C., R. Stephan, S. Johler, N. Borel, J. Bünter, R. M. Bruckmaier, and O. Wellnitz. 2014. The inflammatory response of primary bovine mammary epithelial cells to Staphylococcus aureus strains is linked to the bacterial phenotype. PLoS One 9:e87374. https://doi.org/10.1371/journal.pone.0087374. 